\title{
Consumer Behaviour and Supermarkets in Argentina
}

\section{Elsa Rodríguez, Miriam Berges, Karina Casellas, Rosángela Di Paola, Beatriz Lupín, Laura Garrido and Natacha Gentile*}

\begin{abstract}
This article examines supermarket development from the perspective of differences over regions and categories of consumers. It shows that, controlling for region, the more the education, income, durable assets (car, refrigerator) and consumer credit (credit card) of the consumer, the greater the probability that he/she will shop at a supermarket. Controlling for personal characteristics, living in a northern region (poorer, more rural, poorer infrastructure) reduces the probability of shopping at a supermarket. Finally, Argentinian consumers are less likely to buy fresh fruit and vegetables, red meat, and bread at a supermarket, as they would rather buy these from shops offering personal attention and service for those products.
\end{abstract}

Globalisation, combined with structural adjustment (economic deregulation, market liberalisation, privatisation of public enterprises, etc.), have together created a new macroeconomic context in the past decade in Argentina. In this new context, the food market has undergone profound changes, requiring producers, processors, and distributors to carry out co-ordination and integration of the supply chain. To meet the new rules of the game, firms have had to adapt their production, processing, logistical, and marketing structures to the specifications of consumer demand (Kinsey and Senauer, 1996). This has brought change in marketing systems, in particular the rapid rise of supermarkets and hypermarkets at the expense of traditional retailers and small, full-service shops. AC Nielsen Argentina (1999) shows that in 1984, over the whole country, supermarkets had $27 \%$, modern self-service ('convenience') stores $17 \%$, and traditional shops $56 \%$ of food retailing. By 1990 , the shares were $34 \%, 21 \%$, and $44 \%$, respectively; and by 1999 supermarkets had $58 \%$, while traditional stores had only $19 \%$ (see Figure 1).

The Argentine economy (measured by GDP) grew by 37.2\% from 1991 to 1998 and with it the supermarket sector, expanding, consolidating and multinationalising. During this period the sector was adapting to a relatively rich consumer and one who was growing richer; growth was therefore accompanied by product differentiation (in type, quality and price). In 1998 the economy entered recession, and from 1998 to 1999 GDP fell by 7\%. INDEC (2002) shows that between 1998 and 2000, there was an increase of $36 \%$ in the number of retail stores in the country but a fall of $23 \%$ in sales (see Table 1).

\footnotetext{
* Elsa Rodríguez (emrodi@mdp.edu.ar) and the other authors are at the Universidad Nacional de Mar del Plata, Argentina.

(c) Overseas Development Institute, 2002.

Published by Blackwell Publishers, Oxford OX4 1JF, UK and 350 Main Street, Malden, MA 02148, USA.
} 


\section{Figure 1: Shares by type of retailer (percentage of the total volume of food retail)}

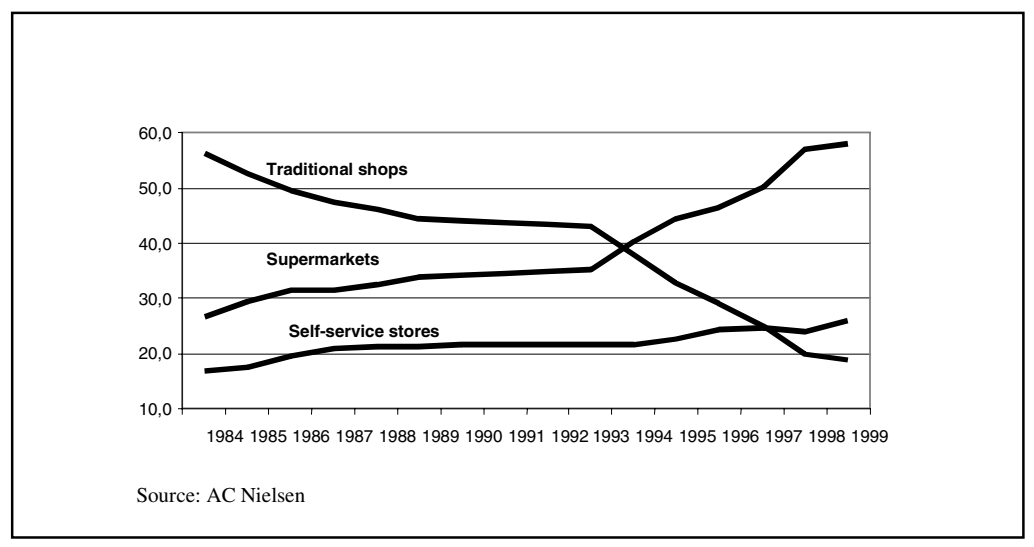

According to the National Institute for Statistics and Censuses (INDEC), in 1999 in the Buenos Aires region, the poorest $40 \%$ of the population earned $13 \%$ of the national income while the richest $20 \%$ earned 53\%. By 2002 the economy had entered a fullblown depression. During the hard times from 1998 on, supermarkets, hypermarkets, and hard discount chains (formed by the supermarket chains to compete for the lowerincome market) focused less on product differentiation and more on cost-cutting and price reduction to sell to Argentine consumers suddenly much poorer than they had been in the mid-1990s.

\section{Table 1: Evolution of super and hypermarkets in Argentina, 1998-2000 (\%)}

\begin{tabular}{lcccccc}
\hline Variables & $\begin{array}{c}\text { Total } \\
\text { Argentina }\end{array}$ & Metro & Pampa & $\begin{array}{c}\text { North } \\
\text { NW + NE }\end{array}$ & Cuyo & Patagonia \\
\hline $\begin{array}{l}\text { Growth of sales per } \\
\text { store }\end{array}$ & -30 & -42 & -18 & -20 & -13 & -14 \\
$\begin{array}{l}\text { Growth of number } \\
\text { of stores }\end{array}$ & 36 & 66 & 14 & 20 & 21 & 21 \\
$\begin{array}{l}\text { Growth in floor } \\
\text { space of stores }\end{array}$ & 23 & 25 & 16 & 23 & 39 & 25 \\
\hline
\end{tabular}

Source: Authors' calculations based on INDEC data.

Various studies have examined the rise of supermarkets and fast-food chains and their effects on food supply chains in Argentina (see Gutman and Ghezan et al. in this volume), but few have focused on their links with consumer behaviour and preferences and the development of their marketing strategies. This article addresses that gap by focusing on consumer habits with respect to supermarkets. We analyse the two-way effect of consumers' preferences and needs on supermarket strategies, and of 'retail supply' on consumers, taking into account their socio-economic differences. Moreover, most work on supermarkets in Argentina has stressed the difference between the 
Greater Buenos Aires area and the interior of the country, and there is a dearth of analysis on the differences among regions. We therefore include geographic differentiation in our analysis, from both the consumer and the supermarket perspectives. This enriches the story of the links between consumers and supermarkets by adding a new dimension to the differentiation of types of consumers.

\section{Supermarket development and consumer behaviour and characteristics by region}

Each of Argentina's six regions is distinct in terms of population density, economic activities, degree of linkage with the global economy, and socio-economic characteristics of households. The six are: the Metropolitan Area, including Greater Buenos Aires, the Pampa region (the grain and cattle belt in the centre-east, inland from Greater Buenos Aires), Northwest region, Northeast region, Cuyo region (the livestock, fruit and vegetable area in the centre-west, inland from the Pampa and Metro areas, near the Andes), and the vast sparsely populated cattle-producing Patagonia region, in the south. The contrasts in lifestyles and cultures of the regions have led to differentiated strategies by the supermarket chains.

Table 2 shows the main characteristics of the regions. It should be noted that the geographic distribution of people and income is extremely concentrated; $79 \%$ of income and $76 \%$ of the population are concentrated in the Metro and Pampa regions, which together make up only about $15-20 \%$ of the national territory. The population is spread more or less evenly over the other four regions, the greatest contrast being between Metro and the two northern regions - with Metro having twice the average income and half the poverty rate.

The development and expansion of hyper/supermarkets in the different regions are conditioned by their strategies for capturing the attention of the various socio-economic strata of consumers with their different needs and preferences. The differences among hypermarkets, supermarkets, and small self-service 'convenience' stores (including 'hard discounts') are based on the number of cash registers per store; hypermarkets have more than 45, supermarkets between 4 and 44, and convenience stores between 1 and 3. What we classify as 'traditional shops' are small stores tending to sell only one category of product and being 'full service' rather than self-service.

In Metro and the large cities of the Pampa, there are two consumer groups with different lifestyles and thus different consumer behaviour and demand. On the one hand there are upper- and middle-income households whose heads (a term we use for the adults responsible for food purchase decisions) work long hours and shop at hypermarkets in order to make large-volume, less frequent purchases, looking for convenience and low prices. On the other hand are the lower-income households, including the unemployed, resident outside city centres and in the periphery, whose low purchasing power drives them towards local shops and convenience stores. In the Northwest and Northeast regions, consumer habits have changed more slowly than in the central regions; consumers have tended to stick with traditional purchase patterns making home purchases from itinerant vendors, and going to street fairs that make the weekly rounds of neighbourhoods, and market-place markets (covered or open-air). But they have recently also begun to shop at the new hypermarkets in their area, which 
double as shopping and recreation points for the families. In Patagonia, sparse population and long distances lead consumers to use supermarkets in order to be able to shop in one place for all household needs.

\section{Table 2: Characteristics of the regions}

\begin{tabular}{|c|c|c|c|c|c|c|c|}
\hline Variables & $\begin{array}{l}\text { Whole } \\
\text { country }\end{array}$ & Metro & Pampa & $\begin{array}{l}\text { North- } \\
\text { west }\end{array}$ & $\begin{array}{l}\text { North- } \\
\text { east }\end{array}$ & Cuyo & $\begin{array}{c}\text { Patag- } \\
\text { onia }\end{array}$ \\
\hline $\begin{array}{l}\text { Monthly income per capita } \\
\text { (average in US\$) }\end{array}$ & 300 & 364 & 283 & 197 & 199 & 240 & 310 \\
\hline$\%$ of income spent on food & 34 & 33 & 34 & 36 & 38 & 31 & 30 \\
\hline $\begin{array}{l}\% \text { of households below the } \\
\text { regional poverty line }{ }^{a}\end{array}$ & 32 & 24 & 33 & 50 & 51 & 43 & 39 \\
\hline Persons/sq. km. & 13 & 1724 & 15 & 8 & 12 & 8 & 2.5 \\
\hline$\%$ of population & 100 & 42 & 34 & 8 & 6 & 6 & 4 \\
\hline$\%$ of income & 100 & 49 & 30 & 7 & 5 & 5 & 5 \\
\hline Household average size & 3.6 & 3.4 & 3.4 & 4.5 & 4.1 & 4 & 3.8 \\
\hline $\begin{array}{l}\text { Children }<14 \text { years old } \\
\text { (average per household) }\end{array}$ & 2 & 1.9 & 2. & 2.3 & 2.3 & 2.2 & 2.1 \\
\hline
\end{tabular}

Notes: a) The poverty line is based on the consumption basket weighted by regional prices. Data from Sistema de Información, Monitoreo y Evalución de Programas Sociales (SIEMPRO).

Source: Authors' calculations based on data from INDEC, National Expenditure Survey 1996/7.

We noted above that the numbers of supermarkets and their share in total food retailing grew rapidly in the country as a whole over the 1990s. This generalisation hides substantial differences among the regions. In Metro, the number of supermarkets grew by a huge $66 \%$ over the period $1998-2000$ and store floor space grew by $25 \%$, while sales per square metre fell by $42 \%$. In Cuyo and Patagonia, the number of stores increased by only $21 \%$, but there was an increase in store size and only a small fall in per-store sales. This suggests that only recently, in 2000, supermarket chains were expanding into the interior in order to offset the fall in sales per square metre in the Metro region. The Pampa region, despite its large population share, saw only a $14 \%$ increase in number of supermarkets and a small fall in sales per square metre (18\%).

There is thus a correlation in Argentina between the location of supermarkets and the population density and household incomes of the different regions. The general strategy is to reduce per-store floor space in the Metro area (which also allows penetration into the denser inner-city areas where markets have persisted for traditional stores) and to maintain large store sizes in the interior regions of the country, including opening hypermarkets, since these are attractive to their middle- and lower middle-class households who want family entertainment, product diversity, and lower prices all in one place.

What kinds of traditional shops survive in the interior regions in the context of this trend of rapid supermarket development? In one city in the Pampa region, a study was undertaken in 2000 to see how traditional shops were being affected by the rise of supermarkets in the region. The least affected were those which specialised and thus had a niche market (bakeries, butchers, vegetable and fruit shops), with an emphasis on personalised service to the customer, plus the corner stores that specialise in being open 
24 hours a day. Moreover, the specialised shops emphasise excellent presentation and service, and try to profit from the denser flow of shoppers in the areas near the supermarkets. The traditional shops have also had to lower their prices to compete with the supermarkets, and to lengthen their hours and differentiate their products.

\section{Determinants of consumer's choice of food retailer}

\section{Inter-regional patterns}

In general, the availability of food products (reflected in their prices) and household income determine patterns of food consumption. The Argentine diet is relatively high in basic staples such as bread, cereals, and pasta, and non-staples such as meat, fruit and vegetables, together with some milk products. Bennett's Law predicts that the higher the household income, other things being equal, the higher the share of non-staples in the diet.

However, given the basic diet and its predictable variation among income strata, a number of other factors determine where a consumer shops. One of these is the region where the consumer lives. 'Region' is, of course, a proxy for a set of variables (such as road and population density, history and culture, etc.) that affect shoppers' choice of retailers, controlling for the shoppers' socio-economic characteristics. Table 3 shows food expenditures in the three main retail formats using data from the National Household Expenditure Survey (INDEC, 1996/97) which employed a sample of 27,260 households representing the whole country. A fourth category is 'other retailers' which includes own household food production and purchases from street vendors and fairs. This amounts to only $8 \%$ of the total and is of some significance only in the Metro area, where population density allows such niches, and the Northwest and Northeast, where traditional retail channels still persist.

Despite the advance of the large supermarket chains, 'small stores' are still a major means by which Argentines obtain food. They represent more than 50\% of food purchases in almost all the categories analysed. Argentine consumers clearly prefer to buy bread, meat, and fruit and vegetables from small stores, where they get personal service and are confident of the quality of the products.

Nevertheless, the degree of penetration of the supermarkets was different over regions according to the INDEC data. Figures for the centre-west (our 'Cuyo') and the south (our 'Patagonia') show a higher share, for the reasons discussed earlier (especially distances making it necessary to have one-stop shopping). In a very different environment, the northern regions (our Northwest and Northeast), with a hotter climate and a population mainly with indigenous roots, the small stores and traditional plaza markets ('other retailers') continue to be important.

Not only context-level variables reflected in 'region' play a role in the choice of retailer, but also household socio-economic variables such as income, education, whether there is a maid in the home, and proxies for tastes and lifestyle. We model these in the next sub-section. 
Table 3: Retail sales of food via supermarkets and small stores

\begin{tabular}{|c|c|c|c|c|c|c|c|}
\hline \multirow[b]{2}{*}{ Product } & \multicolumn{7}{|c|}{ Share of purchases from supermarkets and hypermarkets } \\
\hline & $\begin{array}{c}\text { Total for } \\
\text { Argentina }\end{array}$ & Metro & Pampa & NW & NE & Cuyo & $\begin{array}{c}\text { Patag- } \\
\text { onia }\end{array}$ \\
\hline Food and beverages & 27 & 26 & 28 & 15 & 20 & 30 & 49 \\
\hline Bakery products & 16 & 16 & 16 & 7 & 14 & 15 & 31 \\
\hline Flours and grains & 44 & 42 & 47 & 30 & 29 & 53 & 67 \\
\hline Pastas & 39 & 35 & 37 & 29 & 32 & 44 & 65 \\
\hline Beef & 22 & 25 & 22 & 8 & 13 & 24 & 47 \\
\hline Poultry & 30 & 29 & 30 & 13 & 22 & 36 & 50 \\
\hline Fish and shellfish & 21 & 24 & 18 & 10 & 34 & 17 & 35 \\
\hline Sausages and cold-cuts & 44 & 44 & 42 & 30 & 39 & 46 & 63 \\
\hline Milk & 36 & 28 & 31 & 29 & 27 & 47 & 68 \\
\hline Milk products & 48 & 46 & 48 & 34 & 41 & 51 & 69 \\
\hline Fruit & 24 & 24 & 25 & 8 & 14 & 21 & 57 \\
\hline Vegetables & 22 & 23 & 24 & 5 & 13 & 18 & 53 \\
\hline Ready-to-eat foods & 13 & 16 & 11 & 6 & 7 & 12 & 25 \\
\hline Alcoholic beverages & 39 & 50 & 38 & 21 & 25 & 36 & 59 \\
\hline \multirow[t]{2}{*}{ Non-alcoholic beverages } & 29 & 32 & 30 & 15 & 21 & 30 & 49 \\
\hline & \multicolumn{7}{|c|}{ Share of purchases from small stores } \\
\hline Food and beverages & 65 & 66 & 65 & 76 & 69 & 61 & 44 \\
\hline Bakery products & 78 & 81 & 79 & 85 & 78 & 74 & 65 \\
\hline Flours and grains & 53 & 55 & 50 & 67 & 66 & 44 & 31 \\
\hline Pastas & 57 & 62 & 58 & 67 & 64 & 52 & 32 \\
\hline Beef & 75 & 73 & 75 & 89 & 83 & 73 & 51 \\
\hline Poultry & 65 & 68 & 65 & 83 & 68 & 57 & 47 \\
\hline Fish and shellfish & 67 & 74 & 67 & 74 & 42 & 68 & 51 \\
\hline Sausages and cold-cuts & 53 & 54 & 54 & 66 & 62 & 49 & 35 \\
\hline Milk & 58 & 70 & 61 & 64 & 63 & 44 & 29 \\
\hline Milk products & 49 & 52 & 49 & 63 & 54 & 46 & 29 \\
\hline Fruit & 68 & 73 & 70 & 80 & 64 & 68 & 39 \\
\hline Vegetables & 72 & 75 & 70 & 88 & 75 & 75 & 42 \\
\hline Ready-to-eat foods & 72 & 78 & 77 & 66 & 68 & 71 & 64 \\
\hline Alcoholic beverages & 56 & 46 & 57 & 74 & 68 & 56 & 39 \\
\hline Non-alcoholic beverages & 53 & 46 & 51 & 69 & 62 & 50 & 40 \\
\hline
\end{tabular}

Notes: Small stores include: (i) self-service with less than 4 cash registers; (ii) traditional shops.

Source: Authors' calculations based on data of INDEC, National Expenditure Survey, 1996/7.

\section{Inter-household determinants}

To model inter-household determinants of the choice of retailer, we estimated probit functions. The dependent variable takes the value of 1 if the household shops at a given type of retailer, and 0 if it does not. $X$ is the vector of determinants of the decision:

$$
\operatorname{Prob}(Y=1)=F(X, \beta)
$$


$\operatorname{Prob}(Y=0)=1-F(X, \beta)$

The probit model estimates the probability of $\mathrm{Y}$ and $\mathrm{F}$ having a normal distribution.

$$
\begin{aligned}
& \operatorname{Prob}(Y=1)=\int_{-\infty}^{\beta^{*}} \phi(t) d t=\phi(\beta x) \\
& E[y \backslash X]=0\left[1-\phi\left(\beta^{*} X\right)\right]+1[\phi(\beta \cdot X)]=\phi(\beta \cdot X)
\end{aligned}
$$

The $\beta$ vector shows the effects of the determinants on the probability of choosing the retailer type. As it is a non-linear function, the marginal effects need to be calculated as follows:

$$
\partial E[y \backslash X] / \partial X=\phi(\beta \cdot X) \beta
$$

To interpret the estimated model, it is useful to calculate the marginal effects of the average levels of the determinants or at point estimates that would be of interest. In the case of dummy variables (determinant variables that take on 0 or 1), the interesting effect is the intercept difference that the dummy makes to the probability.

The dependent variables in the three estimated models are whether the household buys: (a) in a supermarket or hypermarket (buy@super); (b) in small stores (buy@small); and (c) in other retail (buy@other). The determinant variables are: (a) household income per capita (incomepc); (b) number of household members (hhsize); (c) household head age (ageheadhh); (d) dependency ratio (economically inactive members divided by total members) (depratio); (e) dummy (0/1), if household head has university education (educuniv); (f) if household head has only primary education (educprim); (g) if household has refrigerator (refrig); (h) if household has car (car); (i) if household income is in the lowest quintile of its region (incquint1); (j) or in the highest quintile (incquint5); (k) if household contains children younger than 14 (kids); (l) if household contains persons older than 65 (elderly); (m) if household head is a woman (womanhead); (n) if household head has credit card (creditcard); (o) region = Metro $($ Metro $) ;(\mathrm{p})$ region $=\mathrm{NW}(\mathrm{NW}) ;(\mathrm{q})$ region $=\mathrm{NE}(\mathrm{NE}) ;(\mathrm{r})$ region $=$ Cuyo $(\mathrm{Cuyo}) ;(\mathrm{s})$ region $=$ Patagonia $($ Patagonia $)$.

The variables capture purchasing power (income), opportunity cost of time and thus the cost of shopping (demographic variables), tastes, preferences and lifestyle (education and quintile variables), need for fresh foods and thus frequent shopping (children and elderly), ability to get to the stores, as hypermarkets tend to be located outside town (car), to make large purchases (credit card and income and refrigerator to keep the food bought), controlling for regional effects.

\section{Probit results}

The probability of a household's buying food at a supermarket/hypermarket, given the average levels of the determinants, is $51 \%$. Around that average we can statistically construct two extremes: (i) if a household has a monthly income of $\$ 500$ (instead of the average \$300), the household head is a woman, with university education and at least two dependants, she has a car, a refrigerator, a credit card, and lives in Patagonia, there 
is a $93 \%$ chance the household buys food in supermarkets; (ii) if a household has several young children, a male household head with only primary education and a per capita monthly income half the average, he has no car or credit card and they live in the $\mathrm{NE}$ or NW, then they have only a $17 \%$ chance of buying food in a supermarket.

Table 4 shows the coefficients of the determinants and the marginal effects. The findings are as hypothesised, namely, the probability of a household buying its food in a super- or hypermarket: (i) the higher the income; (ii) the higher the education of the household head; (iii) having a car, refrigerator, and credit card.

\section{Table 4: Probit results}

\begin{tabular}{|c|c|c|c|c|c|c|c|}
\hline Variables & Promedio & $\begin{array}{l}\text { buy@super } \\
\text { coefficients }\end{array}$ & $\begin{array}{c}\text { buy@super } \\
\text { marginal } \\
\text { effects }\end{array}$ & $\begin{array}{l}\text { buy@small } \\
\text { coefficients }\end{array}$ & $\begin{array}{c}\text { buy@small } \\
\text { marginal } \\
\text { effects }\end{array}$ & $\begin{array}{l}\text { buy@other } \\
\text { coefficients }\end{array}$ & $\begin{array}{c}\text { buy@other } \\
\text { marginal } \\
\text { effects }\end{array}$ \\
\hline $\mathrm{C}$ & & -0.3517 & - & 1.6829 & - & -0.6065 & - \\
\hline Incomepc $^{a}$ & 335 & 0.0001 & 0.5 & $-0.0000^{c}$ & - & $-0.0000^{c}$ & - \\
\hline $\mathrm{N}$ & 3.8 & 0.0520 & 2.1 & 0.0653 & 0.4 & 0.0553 & 2.1 \\
\hline Ageheadhh $^{\mathrm{b}}$ & 49 & $0.0073^{\mathrm{c}}$ & - & $-0.0014^{c}$ & - & 0.0016 & 0.6 \\
\hline$\left(\mathrm{n}_{\mathrm{na}} / \mathrm{n}_{\mathrm{a}}\right)$ & 2.3 & $-0.0015^{\mathrm{c}}$ & - & $0.0057^{\mathrm{c}}$ & - & $-0.0076^{\mathrm{c}}$ & - \\
\hline Educuniv & & 0.4084 & 16.1 & $-0.0771^{\mathrm{c}}$ & - & -0.1549 & -5.6 \\
\hline Educprim & & -0.2455 & -9.5 & $0.0413^{\mathrm{c}}$ & - & $0.0004^{\mathrm{c}}$ & - \\
\hline Refrig & & 0.1101 & 4.4 & $-0.016^{\mathrm{c}}$ & - & $0.0169^{\circ}$ & - \\
\hline Incquint1 & & -0.3089 & -12.0 & 0.1055 & 0.7 & -0.2248 & -8.1 \\
\hline Incquint5 & & 0.1701 & 6.8 & $-0.072^{c}$ & - & 0.0697 & 2.6 \\
\hline Car & & 0.1723 & 6.9 & -0.0984 & -0.8 & 0.1243 & 4.8 \\
\hline Credit card & & 0.0636 & 2.5 & 0.0939 & 0.6 & 0.1470 & 5.6 \\
\hline Kids & & $-0.0320^{c}$ & - & $0.0355^{\mathrm{c}}$ & - & 0.0457 & 1.7 \\
\hline Elderly & & 0.0524 & 2.1 & $0.0078^{\mathrm{c}}$ & - & $-0.0214^{\mathrm{c}}$ & - \\
\hline Womanhead & & 0.0651 & 2.6 & -0.1073 & -0.9 & -0.1282 & -4.7 \\
\hline METRO & & -0.1665 & -6.5 & 0.1689 & 1.0 & 0.2481 & 9.6 \\
\hline NW & & -0.2934 & -11.3 & 0.6119 & 2.5 & 0.1731 & 6.7 \\
\hline $\mathrm{NE}$ & & -0.1584 & -6.2 & $0.0963^{\mathrm{c}}$ & - & 0.2361 & 10.2 \\
\hline CUYO & & 0.3372 & 13.4 & $-0.0537^{\mathrm{c}}$ & - & 0.1738 & 6.7 \\
\hline PATAGONIA & & 0.5377 & 21.0 & -0.6272 & -7.9 & -0.401 & -13.7 \\
\hline R-McFadden & & 0.081 & & 0.088 & - & 0.032 & \\
\hline
\end{tabular}

Notes: Marginal effects were not calculated for non-significant coefficients. a) the marginal effects are measured for each 10 years; b) the marginal effects are measured for each $\$ 100$; c) statistically significant at $5 \%$.

On the whole, an average household has a $96 \%$ probability of buying from 'small stores' as defined above (small traditional shops or self-service convenience stores or hard discounts). This means that most households that shop at supermarkets also buy part of their food from these small stores. With respect to the probability of a household buying from 'other retailers' the chance is surprisingly high (36\%) but the volume of purchases is very small on average, a little from a street fair here, a purchase from a kiosk there, and so on. 
We repeated the analysis but with the data for the different regions disaggregated, and the main results were maintained. Thus, apart from the regional influences on the probability of buying from a super- or hypermarket as discussed, the fundamental socioeconomic determinants operate across households per region; richer, more educated households tend to shop at supermarkets. The average probabilities per region are: $46 \%$ for Metro, $51 \%$ for Pampa, $41 \%$ and $44 \%$ for Northwest and Northeast, and $63 \%$ and $72 \%$ for Cuyo and Patagonia.

An interesting region-specific result is the negative coefficient on the Metro dummy. This indicates that households that live in the capital tend, given their socioeconomic characteristics, to shop less at supermarkets relative to similar households in the Pampa. This is not surprising if one looks at the patterns of growth in supermarkets (Table 1), with increasingly smaller supermarket stores opening in the Metro region, owing to the density and congestion of the city.

While the supermarket clientele does not tend to include the poorest and instead tends to comprise the middle and lower-middle as well as upper-income households, the same clarity of income distribution does not manifest itself for small stores. Admittedly, the poorest shop at small traditional shops in order to buy small amounts, pay in cash, or receive informal credit, or simply because they live in areas where supermarkets have not yet penetrated. But richer households also buy from small shops based on the quality and service and the atmosphere/presentation of the better stores. In the Metro area and in large cities, with high population density and high relative incomes, there is a flourishing of specialised 'food boutiques' to serve these demanding and informed consumers.

To explore differentiation of supermarket buying habits among categories of products, we estimated the probit models again, with the decision variable being whether consumers bought in supermarkets for particular categories of product: bread, grains and flour, pastas, beef, chicken, fish and shellfish, sausages and cold-cuts, milk and milk products, fruit, vegetables, alcoholic and non-alcoholic beverages, and readyto-eat dishes.

The results of the probits applied to each product category indicate behaviour based on an 'income effect' and a 'product effect'. The income effect is that, for all the products, the probability that a household will buy the product in a supermarket increases with family income. The product effect is that, for all levels of income, there is always a higher probability that a household will buy meat, vegetables, fruit, and bread in small stores. A study of beef consumption (Rodríguez, 1990) showed the relative resistance of the Argentine consumer, independent of his/her level of income, to packaged beef (a method of presentation introduced by supermarkets) because they distrust the quality (when meat is packaged) and pre-packaging denies them the chance to select the specific cuts they want. More than ten years after that study, our results show that Argentines have not changed in this respect, and this has led supermarkets to also sell unpackaged beef.

It is interesting that there has been a rapid increase in the consumption of chicken (mirroring global trends), because of its lower price, the wide range of chicken products available and the flexibility of its culinary use. The rise of chicken consumption has favoured supermarkets because of their cold chain facilities and because, unlike beef, chicken presents no disadvantage for them in service, presentation, and marketing. 
Finally, it should be noted that in Argentina at present there is a clear segmentation of consumers, between those with high purchasing power, high opportunity cost of time, and demanding high quality, and those who are poor either structurally or because of the recession and now depression, and the increasing unemployment it has generated. Faced with this consumer differentiation, the retail sector is responding with different strategies: offering diverse services, such as e-commerce for the purchase of food via the internet, to satisfy the richer group; or marketing private label or generics, of good quality but at low prices, to capture the market of the poorer group.

The latter strategy has given rise to a specific format. Towards the end of the 1990s, various supermarket chains began to operate a type of store hitherto unknown in Argentina, the 'hard discount', a small store with less than $500 \mathrm{~m}^{2}$, few employees (one person for each $100 \mathrm{~m}^{2}$ ) with one or two cash registers and selling mostly food and cleaning articles and toiletries, mainly under private label or generics, and at very low prices. By 2000 there were 300 hard discounts in the country, with, according to an analysis by the Latinpanel Company, $24.6 \%$ of consumer traffic at a national level, mainly in foods $(23.8 \%)$, cleaning articles $(15.4 \%)$, and toiletries (13\%). This provides a window into the interpretation of the high share of consumers going to small stores. Moreover, the hard discounts both compete with supermarkets and are themselves creatures of the supermarket chains.

A study undertaken in 2001 by AC Nielsen showed that the poorest have increased their shopping in small neighbourhood shops and the hard discounts in the past few years, driven by declining incomes and lack of credit cards or cars to get out to the shopping centres on the outskirts of the cities. The private label products sold by hard discounts are also eating into the leading brands' market via this shift on the part of poorer buyers: leading brands lost 5\% of the food market in 1998-2000.

\section{Conclusion}

This article contributes to the literature in Latin America on links between consumer preferences and the rise of supermarkets in three respects.

First, our results show that consumer preferences and incomes have conditioned the regional pattern of the diffusion of supermarkets in Argentina. They have also influenced their location and the formats they use, and even the new chains of nonsupermarket formats such as hard discounts that they create to respond to consumer needs for cheap food in the inner cities.

Second, our results show that the higher the household income as well as the capacity (credit cards, cars, refrigerators) and incentive (opportunity cost of time), the greater the probability that a household will shop at supermarkets and hypermarkets. This tendency is independent of region, but it turns out that the two main regions of the country (with three-quarters of the income and the population), the Greater Buenos Aires region and the Pampa region, have the greatest concentration of supermarkets. All this is not to say that supermarkets are not already important and becoming more so in the interior and for those with more modest incomes, but the process is more recent. Some of the gains made by supermarkets among those with modest incomes and in the interior result from their convenience, the mix of products and places of entertainment, and the availability of cheap products, such as chicken. 
Third, supermarkets have not held total sway in the food market, because of the small store chains of self-service hard discounts and convenience stores, but also because of the persistence and success of traditional small shops. While it is incontrovertible that thousands of small shops have been forced out of business by the rise of supermarkets and hard discounts, many have successfully defended niches, based on quality, service and proximity. These niches have been particularly in products for which Argentines especially value freshness and the retailer's adaptation to their specific needs: red meats, fruit, vegetables, and breads.

\section{References}

AC Nielsen Argentina (1999) Censo del Comercio Minorista 1997/1998. Buenos Aires: AC Nielsen SA.

Instituto Nacional De Estadistica y Censos (INDEC), Encuesta de Supermercados and INDEC Informa (various issues 1998-2001).

INDEC, National Household Expenditure Survey (various issues).

Kinsey, J. and Senauer, B. (1996) 'Consumer Trends and Changing Food Retailing Formats', American Journal of Agricultural Economics 78 (5) December: 1187-91.

Rodriguez, E. (1990) 'Consumo de carne vacuna por cortes y sustitutos: Un enfoque de corte transversal', Revista Argentina de Economía Agraria IV. Asociación Argentina de Economía Agraria. 